\title{
ARTIKEL DOUBLE LINKED LIST CIRCULATE (DLLC)
}

\author{
Aria Sakti Nugraha \\ 185100059 \\ Fakultas Komputer \\ ariasaktinugraha.student@umitra.ac.id
}

\begin{abstract}
Linked List adalah suatu struktur data linier. linked list dibentuk secara dinamik. Pada saat awal program dijalankan elemen linked list belum data. Elemen linked list (disebut node) dibentuk sambil jalan sesuai instruksi. sebuah node linked list diakses dengan menggunakan pointer yang mengacu ke node tersebut.

Banyak yang mengira Double Linked List Circulate adalah Double Linked List Circulate pointer next dan prev nya menunjuk ke dirinya sendiri secara circular. Memang benar demikian tapi Double Linked List Circulate tidak hanya itu saja
\end{abstract}

Kata Kunci : Penjelasan Double Linked List Circulate.

\section{A. PENDAhULUAN}

Materi Kuliah Membahas Tentang Pengantar Struktur Data membahas Double Linked List Circulate. Pesatnya teknologi komputer sudah tidak bisa dipungkiri lagi, bagi yang mengikuti perkembangannya, ia tidak akan dipandang sebelah mata. Sebaliknya, bagi yang tidak mengikuti perkembangannya, bersiaplah untuk mundur secara suka rela dari panggung kompetisi
Ibarat wabah, teknologi komputer sudah menyusupi hampir semua bidang kehidupan manusia dari pemerintah pusat hingga tingkat pemerintah desa, perusahaan-perusahaan, supermarket, minimarket, perguruan tinggi, SLTA, SLTP, bahkan SD hampir semuanya mengenal komputer.

Saat ini yang mempunyai linkungan yang semakin luas dan banyak diminati juga dapat 
digunakan untuk menghasilkan uang adalah dunia pemrograman komputer, dikenal banyak bahasa pemrograman, seperti $\mathrm{C}, \mathrm{C}++$, Pascal, Basic, Java, dan lainlain.

Jika dikembangkan dari berbagai bahasa pemrograman ini terdiri dari beberapa struktur data, dan diantaranya adalah linked list. Dalam pemakaian sehari-hari istilah linked list adalah kumpulan linear sejumlah data. Banyak contoh yang menunjukkan senarai berantai seperti pada daftar belanjaan, yang berupa barang pertama, kedua, ketiga dan seterusnya. Untuk hari berikutnya, maka daftar tersebut bisa berubah sesuai dengan barang yang harus dibeli lagi atau barang yang tidak perlu dibeli lagi. Kemudian hari kedua belanja lagi tiga buah barang dan menghapus dua barang yang telah tidak terpakai dari daftar barang yang telah dibeli hari kemarin, hal ini dapat diartikan sebagai senarai beranta. Daftar presensi kelas dimana terdapat list dari siswa yang berurut sesuai NIM. Selain itu juga ada Daftar menu makanan pada restoran yang menyajikan menu urut dari harga terendah hingga termahal. Dan juga bisa digunakan untuk menyajikan daftar list lagu dalam pembuatan aplikasi pemutar musik.
Pengolahan data yang kita lakukan menggunakan komputer sering kali mirip dengan ilustrasi di atas, yang antara lain berupa penyimpanan data dan pengolahan lain dari sekelompok data yang telah terorganisir dalam sebuah urutan tertentu. Salah satu cara untuk menyimpan sekumpulan data yang kita miliki adalah menggunakan larik.

Keuntungan dan kerugian pemakaian larik untuk menyimpan sekelompok data yang banyaknya selalu berubah dan tidak diketahui dengan pasti kapan penambahan atau penghapusan akan berakhir.

Linked List adalah suatu struktur data linier. Berbeda dengan array yang juga merupakan struktur data linier dan tipe data komposit, linked list dibentuk secara dinamik. Pada saat awal program dijalankan elemen linked list belum data. Elemen linked list (disebut node) dibentuk sambil jalan sesuai instruksi. Apabila setiap elemen array dapat diakses secara langsung dengan menggunakan indeks, sebuah node linked list diakses dengan menggunakan pointer yang mengacu ke node tersebut.

Dalam artikel ini akan dibahas secara detail tentang Double Linked List Circulate 


\section{B. PEMBAHASAN / STUDI KASUS}

Double Linked List Circular adalah linked list dengan menggunakan pointer, dimana setiap node memiliki 3 field, yaitu 1 field pointer yang menunjuk pointer berikutnya (next), 1 field menunjuk pointer sebelumnya (prev), serta sebuah field yang berisi data untuk node tersebut. Double Linked List Circular pointer next dan prev-nya menunjuk ke dirinya sendiri secara circular.

\section{a. Bentuk Node DLLC}

Double : field pointer-nya terdiri dari dua buah dan dua arah, yaitu prev dan next.

Linked List : node-node tersebut saling terhubung satu sama lain.

Circular : pointer next dan prev-nya menunjuk ke dirinya sendiri.

Ilustrasi Double Linked List Circular

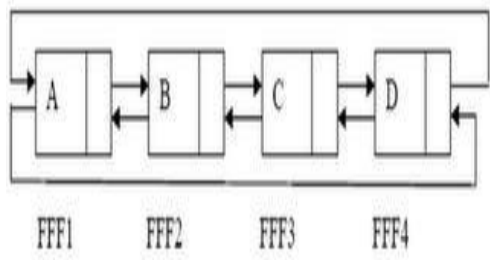

- Setiap node pada linked list mempunyai field yang berisi data dan pointer ke node berikutnya dan ke node sebelumnya.

- Untuk pembentukan node baru, mulanya pointer next dan prev akan menunjuk ke dirinya sendiri.
- Jika sudah lebih dari satu node, maka pointer prev akan menunjuk ke node sebelumnya, dan pointer next akan menunjuk ke node sesudahnya.

\section{b. Pembuatan Double Linked List Circular}

Deklarasi node, dibuat dari struct berikut ini:

Penjelasan:

- Pembuatan struct bernama TNode yang berisi 3 field, yaitu field data bertipe integer dan field next dan prev yang bertipe pointer dari Tnode.

- Setelah pembuatan struct, buat variabel haed yang bertipe pointer dari TNode yang berguna sebagai kepala linked list.

Pembuatan Node Baru:

Digunakan keyword new yang berarti mempersiapkan sebuah node baru berserta alokasi memorinya, pointer prev dan next menunju ke dirinya sendiri.

\section{c. Double Linked List Circular Menggunakan Head}

- Menggunakan 1 pointer head.

- Head selalu menunjuk node pertama. Deklarasi Pointer Head: 
Manipulasi linked list tidak bisa dilakukan langsung ke node yang dituju, melainkan harus melalui node pertama dalam linked list. Deklarasinya sebagai berikut:

\section{d. Penambahan Data}

Penambahan Data di Depan:

Penambahan node baru akan dikaitan di node paling depan, namun pada saat pertama kali (data masih kosong), maka penambahan data dilakukan pada headnya. Pada prinsipnya adalah mengkaitkan data baru dengan head, kemudian head akan menunjuk pada data baru tersebut sehingga head akan tetap selalu menjadi data terdepan. Dibutuhkan pointer bantu yang digunakan untuk menunjuk node terakhir (head prev) yang akan digunakan untuk mengikat list dengan node terdepan.

\section{Penambahan Data di Belakang:}

Penambahan data dilakukan di belakang, namun pada saat pertama kali data langsung ditunjuk pada head-nya. Penambahan di belakang lebih sulit karena kita membutuhkan pointer bantu untuk mengetahui data terbelakang, namun tidak diperlukan loop karena untuk mengetahui node terbelakang hanya perlu menunjuk pada head prev saja.
Kemudian dikaitkan dengan data baru. Untuk mengetahui data terbelakang perlu digunakan perulangan.

- Function di atas digunakan untuk menampilkan semua isi list, dimana linked list ditelusuri satu-persatu dari awal node sampai akhir node. Penelusuran ini dilakukan dengan menggunakan suatu variabel node bantu, karena pada prinsipnya variabel node head yang menjadi tanda awal list tidak boleh berubah/berganti posisi.

- Penelusuran dilakukan terus sampai node terakhir ditemukan menunjuk ke head lagi. Jika belum sama dengan head, maka node bantu akan berpindah ke node selanjutnya dan membaca isi datanya dengan menggunakan field next sehingga dapat saling berkait.

- Jika head masih NULL berarti data masih kosong.

\section{e. Penghapusan Data}

- Function di atas akan menghapus data teratas (pertama) yang ditunjuk oleh head pada linked list.

- Penghapusan node tidak boleh dilakukan jika keadaan node sedang ditunjuk oleh pointer, maka harus ditampung dah ulu pada pointer hapus dan barulah kemudian menghapus 
pointer hapus dengan menggunakan perintah delete.

- Jika head masih NULL maka berarti data masih kosong.

- Diperlukan pointer bantu yang mengikuti pointer hapus yang berguna untuk menunjuk ke node sebelum terakhir.

- Kemudian pointer hapus ditunjukkan ke node setelah pointer bantu, kemudian hapus pointer hapus dengan perintah delete.

\section{f. Double Linked List Menggunakan Head dan Tail}

- Dibutuhkan dua buah variabel pointer: head dan tail.

- Head akan selalu menunjuk pada node pertama, sedangkan tail akan selalu menunjuk pada node terakhir.

Pengkaitan Node Baru ke Linked List di Depan:

Penambahan node baru akan selalu dikaitan di node paling depan, namun pada saat pertama kali (data masih kosong), maka penambahan data dilakukan pada tail/headnya. Sedangkan jika tidak kosong, data akan ditambahkan di depan head, kemudian node baru akan berubah menjadi head.
Penambahan Node di Belakang:

Penambahan node di belakang akan selalu dikaitkan dengan tail dan kemudian node baru tersebut akan menjadi tail.

- Function di atas akan menghapus data teratas (pertama) yang ditunjuk oleh head pada linked list.

- Penghapusan node tidak boleh dilakukan jika keadaan node sedang ditunjuk oleh pointer, maka harus ditampung dahulu pada variabel hapus dan barulah kemudian menghapus variabel hapus dengan menggunakan perintah delete.

- Jika tail masih NULL maka berarti data masih kosong.

- Pointer hapus tidak perlu di loop untuk mencari node terakhir. Pointer hapus hanya perlu menunjuk pada pointer tail saja.

Karena pointer hapus sudah bisa menunjuk ke pointer sebelumnya dengan menggunakan elemen prev ke node sebelumnya. Kemudian pointer tail akan berpindah ke node sebelumnya.

\section{ID SECURITY}


QWTD4452377-ASP-5244107

\section{KESIMPULAN}

Kesimpulan yang dapat ditarik dari pembahasan, yaitu:

linked list merupakan sebuah struktur data yang digunakan untuk menyimpan sejumlah objek data biasanya secara t e r u r t s e hi n g a memungkinkan penambahan, pengurangan, dan pencarian atas elemen data yang tersimpan dalam senarai dilakukan secara lebih efektif. Dan juga kita bisa tahu langkah-langkah dalam menggunakan Double Link Listed Circular

\section{E. DISKUSI}

Saya bersama teman saya bernama Rizaldi Bagas Wimawan mendiskusikan tentang contoh ini dengan sangat baik Hasil diskusi dari materi ini adalah :

Saya : Apakah artikel ini membantu anda?

Bagas : Iya, artikel ini sangat membantu untuk saya yang ingin belajar tentang double linked list khususnya yang circulate.

Saya : Apakah anda mempunyai saran untuk artikel ini?

Bagas : Saat memberi petunjuk kegunaan harus disertai gambar agar pembaca lebih mendapat penjelasan.
Saya : Apakah artikel ini layak untuk dipublikasikan?

Bagas : Layak karena artikel ini menggunakan bahasa yang sederhana, jadi mudah dimengerti siapapun yang ingin belajar tentang double linked list circulate.

\section{F. REFERENCE}

[1] O. M. Febriani and A. S. Putra, "Sistem Informasi Monitoring Inventori Barang Pada Balai Riset Standardisasi Industri Bandar Lampung," J. Inform., vol. 13, no. 1, pp. 90-98, 2014.

[2] A. S. Putra, "Paperplain: Execution Fundamental Create Application With Borland Delphi 7.0 University Of Mitra Indonesia," 2018.

[3] A. S. Putra, "2018 Artikel Struktur Data, Audit Dan Jaringan Komputer," 2018.

[4] A. S. Putra, "ALIAS MANAGER USED IN DATABASE DESKTOP STUDI CASE DB DEMOS."

[5] A. S. Putra, "COMPREHENSIVE SET OF PROFESSIONAL FOR DISTRIBUTE COMPUTING."

[6] A. S. Putra, "DATA ORIENTED RECOGNITION IN BORLAND DELPHI 7.0."

[7] A. S. Putra, "EMBARCADERO DELPHI XE 2 IN GPUPOWERED FIREMONKEY APPLICATION."

[8] A. S. Putra, "HAK ATAS 
KEKAYAAN INTELEKTUAL DALAM DUNIA TEKNOLOGY BERBASIS REVOLUSI INDUSTRI 4.0."

[9] A. S. Putra, "IMPLEMENTASI PERATURAN

PERUNDANGAN UU. NO 31 TAHUN 2000 TENTANG DESAIN INDUSTRI BERBASIS INFORMATION TECHNOLOGY."

[10] A. S. Putra, "IMPLEMENTATION OF PARADOX DBASE."

A. S. Putra, "IMPLEMENTATION OF TRADE SECRET CASE STUDY SAMSUNG MOBILE PHONE."

[12] A. S. Putra, "IMPLEMENTATION PATENT FOR APPLICATION WEB BASED CASE STUDI WWW. PUBLIKLAMPUNG. COM."

[13] A "IMPLEMENTATION SYSTEM FIRST TO INVENT IN DIGITALLY INDUSTRY."

[14] A. S. Putra, "MANUAL REPORT \& INTEGRATED DEVELOPMENT

ENVIRONMENT BORLAND DELPHI 7.0."

[15] A. S. Putra, "PATENT AS RELEVAN SUPPORT RESEARCH."

[16] A. S. Putra, "PATENT FOR RESEARCH STUDY CASE OF APPLE. Inc."

[17] A. S. Putra, "PATENT PROTECTION FOR APPLICATION INVENT."

[18] A. S. Putra, "QUICK REPORT IN

PROPERTY
PROGRAMMING."

[19] A. S. Putra, "REVIEW CIRCUIT LAYOUT COMPONENT

REQUIREMENT ON ASUS NOTEBOOK."

[20] A. S. Putra, "REVIEW TRADEMARK PATENT FOR INDUSTRIAL TECHNOLOGY BASED 4.0."

[21] A. S. Putra, "TOOLBAR COMPONENT PALLETTE IN OBJECT ORIENTED PROGRAMMING."

[22] A. S. Putra, "WORKING DIRECTORY SET FOR PARADOX 7."

[23] A. S. Putra, "ZQUERY CONNECTION

IMPLEMENTED

PROGRAMMING STUDI CASE PT. BANK BCA Tbk."

[24] A. S. Putra, D. R. Aryanti, and I. Hartati, "Metode SAW (Simple Additive Weighting) sebagai Sistem Pendukung Keputusan Guru Berprestasi (Studi Kasus: SMK Global Surya)," in Prosiding Seminar Nasional Darmajaya, 2018, vol. 1, no. 1, pp. 85-97.

[25] A. S. Putra and O. M. Febriani, "Knowledge Management Online Application in PDAM Lampung Province," in Prosiding International conference on Information Technology and Business (ICITB), 2018, pp. 181-187.

[26] A. S. Putra, O. M. Febriani, and B. Bachry, "Implementasi Genetic Fuzzy System Untuk Mengidentifikasi Hasil Curian Kendaraan Bermotor Di Polda Lampung," SIMADA (Jurnal 
Sist. Inf. dan Manaj. Basis Data), vol. 1, no. 1, pp. 21-30, 2018.

[27] A. S. Putra, H. Sukri, and K. Zuhri, "Sistem Monitoring Realtime Jaringan Irigasi Desa (JIDES) Dengan Konsep Jaringan Sensor Nirkabel," IJEIS (Indonesian J. Electron. Instrum. Syst., vol. 8, no. 2, pp. 221-232.

[28] D. P. Sari, O. M. Febriani, and A. S. Putra, "Perancangan Sistem Informasi SDM Berprestasi pada SD Global Surya," in Prosiding Seminar Nasional Darmajaya, 2018, vol. 1, no. 1, pp. 289-294. 